\title{
Financial Service Technology in Indonesia: Between Free Market Regime and Consumer Protection
}

\section{Hamzah}

Faculty of Law, Universitas Lampung, Indonesia, Email: agizaddien@gmail.com

\section{Article Info Abstract}

\section{Keywords:}

Fin-tech, Free Markets, Consumer

Protection

\section{How to cite:}

Hamzah, "Financial Service

Technology in Indonesia: Between

Free Market Regime and

Consumer Protection, " Fiat

Justisia: Jurnal Ilmu Hukum 14,

No. 1 (2020): 83-96.

10.25041/fiatjustisia.v14no1.1891
The free market era provided uninterrupted traffic in goods and services throughout the world, and was initially formed to offer benefits. Although there were still protests in technical problems and rising disputes that led a sue to legal institutions, countries agreed to maintain the free market. As a counterpart, the free market cannot ignore consumer's protection as a standard of service. The liability development between consumer and producer relationship arranged from caveat emptor, to caveat vendor and finally to strict liability in the consumer protection system, implies disclosure of information on products and services. This research faces the legal theory of a free market regime with the theory of consumer's protection law. This research proceeds to discuss two main issues. The first issue is an essential of Financial Technology or Fin-tech of services. The second issues is the influence of Fin-tech on the free market and consumer protection. Research uses a normative legal research method and the data obtained are secondary data from literary sources such as literature, articles and internet sites. Results of the analysis shows; first, the free market regime is both an opportunity as well as a challenge, therefore it is still worth to maintain. The consumer protection's regime is the balance point of the free market's regime. Theoretically, consumer's protection must be used as a tool to protect the consumer's interests. Moreover, it could manage the behaviour of service providers. Secondly, the role of the Financial Services Authority is a key to ensuring that balance is still on maintained. Supervision and determination of financial service providers broadly provide information for the public to choose carefullyof their necessity financial services 


\section{A. Introduction}

The development of civilization's lifestyle has been progressing rapidly. Because of information-technology, many services are provided to the public. Lifestyles has changed through time and adjustments. Sociologists believe that one of the factors to social change is technology. ${ }^{1}$ In the 1980's, Alvin Toffler had predicted the development of civilization from an agrarian based society to an industrial society, then moved into an information society that was triggered by technological inventions. The development of informationtechnology is not allowed to become potential in the financial services sector. In the 1990s John Naisbitt described the world megatrend, one of which, was the shift from a labour-intensive economy to an economy with sophisticated technology. ${ }^{2}$ Still in the same era, Patrick Young and Thomas Theys told about the revolutionary changes in the capital market sector in the 1990's due to computer technology. ${ }^{3}$

In the beginning, computers' functions were limited as typing engines, its functions has evolved in advanced connections to networks with other computers. Afterwards, the network encourages the development of information-technology that is applied to various communication media. Change takes place quickly. World news are spread very quickly to all corners of the world that reach out to innumerable of people. The progress of information-technology is utilized in all lines of life and business, including the financial services sector. The world is more lively and colourful with information-technology. At first, computer creators only thought about machines that were more sophisticated than typewriters. Then it evolved in all aspects of people's lives, including the financial services sector.

In the financial services sector, nowadays, the term financial technology or fin-tech is so popular. Once Walker describes the enormity of the influence of information-technology.

Financial technology (Fin-tech) has emerged as a powerful new market force, as a result of the coming together of a number of disconnected trends. Significant advances have occurred in the areas of computer and digital technology, the Internet, mobile telecommunications, and economics and finance, which have transformed traditional areas of study and created important potential new business structures and operations. ${ }^{4}$

The strength or privilege of information-technology supports an innovation for businesses in the financial services sector. Adoption of technological privilege in the financial services sector are driving rapid development, if not radical or revolutionary and forming markets. Currently, there are numerous

\footnotetext{
${ }^{1}$ Bruce Cohen, Sosiologi: Suatu Pengantar (Jakarta: Bina Aksara, 1983), 59.

${ }^{2}$ John Naisbitt, Megatrends Asia (Jakarta: Gramedia, 1996), 205.

${ }^{3}$ Patrick Young, Thomas Theys, Capital Market Revolution: The Future of Markets in an Online World (London: Prentice Hall, 1999), 1.

${ }^{4}$ George Walker, "Financial Law: A New Beginning and a New Future," Best of ABA Section International Law 50, No. 1 (2017): 76. 
financial services rising with information-technology and networks based platforms or service. There are several public terms used in the society to refer these services such as unsecured loans, online loans, online credit and online investment. Promptitude or accuracy are aspects of information-technology usage in the financial services sectors which are considered advantages to society.

According to sociologists, if development and technological change are accelerated, then the cultural adjustment must also be encouraged. Sociologicaly, it means the shift and development of tehcnology indicate alteration in the society's act of behavior. There are values that indeed bind the cohesiveness of a society. In addition to sociological perspective, the law is indirectly evolved because there is development in society which is factored by information-technology accessibilty in the financial services sector. ${ }^{5}$

Initially, development and use of technology (information-technology) was directed as efforts to facilitate and to help the society. Moreover, the government provides services, authorities and legal provisions to maintain the benefits of financial technology for the society's convenience.

As stated by Shellagh Heffernan in the mid-1990s, "will advantages of FinTech lead the disappearance of banks' involvement?" Furthermore, Heffernan writes:

"It is certainly true that non-banks have begun to offer financial services. For example, General Electric Capital (GE Capital) is the financial services subsidiary of General Electric. It has the largest issuance of commercial paper in the USA, supplies credit card facilities to department stores, is the largest insurer of private homes, and for nine years owned securities firm, Kidder Peabody". 6

Twenty years ago, it was predicted that the financial services sector was not only filled by conventional financial service providers such as banks but also there were non-bank as a financial service provider, as we have seen today. The existence of fin-tech financial services is developing along with the development and domination of information-technology in today's life. Society has a choice to fulfil their need for funds or payment systems or transactions. In the financial services market, fin-tech service providers compete with banks to provide loan services with the convenience and the speed process.

Every change or development brings a negative side and/or access. This is seen in its years the society's progress. Undeniably, online loans provide solutions to the society's urgent financial situation since the procedures are fast and does not require physical encounter; simply by using the available

\footnotetext{
${ }^{5}$ Christopher G. Bradley, "Fintech's Double Edges," Chicago-Kent Law Review 93, No. 1 (2018): 61.

${ }^{6}$ Shellagh Heffernan, Modern Banking in Theory And Practice, (New York: John Wiley And Sons, 1996), 29.
} 
application. However, the Government through Indonesia Financial Services Authority or Otoritas Jasa Keuangan (OJK) cannot ignore the situation. OJK is an institution that has the authority to supervise the financial services sector, including the fin-tech service provider. Certification is one of OJK's efforts to control fin-tech service providers.

This research will focus on analyzing the legal aspects of financial services fin-tech that are endemic in society including pros and cons or positive and negative perspective throughout the execution. There are two aspects of the law that intersect in the fin-tech sector, namely laws relating to free markets and consumer protection laws. This research proceeds to discuss two main issues. The first issue is an essential of financial technology services. The second issues is the influence of Fin-tech on the free market and consumer protection. In principle, anyone who engages in the financial services sector is given the opportunity, but what needs to be kept in mind is respect for consumer protection laws.

\section{B. Discussion}

\section{The Essential of Financial Technology Services}

The banking sector has a unique service, namely the distribution of funds in the form of credit or loans for the consumer and productive sectors. Several procedures and requirements are attached to banking credit services. The procedures start with the loan/credit applicant filling out the form provided by the bank and the loan/credit application itself. Afterwards, the applicant is asked to provide collateral for the loan's application. This stage is a precautionary principle act where loans/credits must be supported with a guarantee to anticipate irresponssible credit. Lastly, the applicant waits for the loan/credit application's approval and disbursement. With this system, the banking sector can still distribute the funds while securing the bad loans ratio limitation.

Currently, financial services are not only provided by banks or companies that engaged in the financial sector, but there are application companies that have application systems where the services and transaction traffic that follows are carried out. Without meetings between service providers and service users, loan transactions can be completed, and agreements available on the application become the legal basis. That is a feature of financial technology or fin-tech.

Development of fintech usage world wide has started since 1800's through the rise of telegraph. Since then, progress of fintech's application continuously increased especially in thecurrent digital era. ${ }^{7}$ Fin-tech is a combination of two aspects, namely financial services and technology which implies the need for

\footnotetext{
${ }^{7}$ Aam Slamet Rusydiana, "Bagaimana Mengembangkan Industri Fintech Syariah di Indonesia? Pendekatan Interpretive Structural Model (ISM)," Jurnal Al-Muzara'ah 6, No. 2 (2018): 118. 
laws and regulations for its implementation. Fin-tech, as a manifestation of the advancement of information-technology that used in the financial services sector, indeed cannot be separated from the interests of the parties, namely service providers and users or consumers. Both aspects must be in a balance point and corridor that refers to the rule of law.

Historically, fin-tech has been known for a long time since the 18th century. It was noted that the first generation fin-tech relied on an analogue system called fin-tech 1.0. Analog system is a signal processing system whose data is processed in a continuous or in gradual. ${ }^{8}$ The next development is fintech 2.0 , which has strong characteristics in globalization and digitalization. ${ }^{9}$ It is happened in the 1980s to the millennium era. The era of fin-tech 3.0 is characterised by a payment system or financial service products that are mobile ${ }^{10}$ and online-based and massive service platforms. ${ }^{11}$ Innovation in the field of information-technology will always be interesting to be utilized by the financial services sector which is not constrained by national borders, time and instantaneous.

Nowadays, financial services are not only provided by well-known financial services companies such as banks but are also provided by application companies. It remains to be seen how the existence of fin-tech services in the next few years.

There are a few things that require the attention of the authorities, service providers and the public regarding this fin-tech.

A critical new element will be the creation of a whole new set of digital rights, interest, entitlements, claims, and record devices that allow of the creation, holding, transfer, exercise, and cancellation of financial rights safely, securely, and efficiently. This will inevitably arise as a result of the conversion and transformation of underlying existing legal rights into a digital form and origination through the creation of new digital entitlements. ${ }^{12}$

There are many legal issues that arise in fin-tech as stated above. Moreover, there are three indicators that form fin-tech, namely efficiency, safety and comfort.

To be sure, fin-tech offers advantages. According to Douglas W., Arner Janos, Barberis Ross and P. Buckley, fin-tech has the advantage of providing solutions. ${ }^{13}$ The solution is in the form of an immediate transaction settlement

\footnotetext{
8 January 2, 2020. https://www.andalanelektro.id.

9 Douglas W. Arner, Jànos Barberis, Ross P. Buckley, "The Evolution of Fintech: A New PostCrisis Paradigm?," Georgetown Journal of International Law 47, No. 4 (2016): 1276.

${ }^{10}$ Ibid.

${ }^{11}$ January 2, 2020. https://ekonomi.kompas.com/read/2017/09/25/183423826/fintech-20-dan30-apa-bedanya.

${ }^{12}$ George Walker, Op.Cit., 77.

${ }^{13}$ The term's origin can be traced to the early 1990s and the Financial Services Technology Consortium, a project initiated by Citigroup to facilitate technological cooperation efforts. The term now refers to a large and rapidly growing industry representing between $\$ 12$ billion and $\$ 197$ billion in investment as of 2014, depending on whether one's industry measurement
} 
through the application. Christopher Bradley later added, the advantages of fin-tech were its ability to reduce transaction costs and benefit the society by advancing or improving chip design and advancing in communication and information-technology that provides so many ATMs (Automatic Teller Machines) in various places; which in turn benefits traders and consumers while the (negative) impact is neutral. ${ }^{14}$ The effect of fin-tech is considered high risk and in some circumstances invite more problems to the community. However, due to the technological progress, it must be accommodated and anticipated by law.

It is interesting to wait for the continuence of fin-tech in the Indonesian financial services market. The existence of fin-tech is based on two significant regimes namely the Free Market Regime and the Consumer Protection Regime. Both are close together in organising fin-tech in Indonesia.

\section{The Influence of Fin-tech on the Free Market and Consumer Protection}

\section{a. Free Market Regime}

The potential market for the users of fintech services is very broad essentially all of the adult population of the globe. ${ }^{15}$ The existence of fin-tech is inseparable from the free-market era. Adam Smith believes that the free market is given an advantage to every party. For Smith, the free market is suitable for the modern society and believed that the free market as the best system for modern economic society. ${ }^{16}$ Smith illustrates the goodness of interstate trade which benefits for both sides where commodity prices and quantities are maintained. ${ }^{17}$ Friedrich A. Von Hayek elaborated on Smith's free-market concept. For him, a free market must be distinguished between the order in its strictest sense and a free market economy. ${ }^{18}$ There are two

includes start-ups only (Fin-tech 3.0) or the full spectrum of applications, including traditional financial institutions (Fin-tech 2.0). It is only since 2014 that the sector has attracted the focused attention of regulators, industry participants, consumers, and academics alike. Given the fundamental role Fin-tech plays in the functioning of finance and its infrastructure, greater regulatory attention is warranted. Fin-tech today is often seen as a uniquely recent marriage of financial services and information technology. However, the interlinkage of finance and technology has a long history. In fact, financial and technological developments have long been intertwined and mutually reinforcing. Douglas W. Arner, Jànos Barberis, Ross P. Buckley, Op.Cit., 1272-1273.

${ }^{14}$ Christopher G. Bradley, Op.Cit., 63.

${ }^{15}$ Svetlana Saksonova, Irina Kuzmina-Merlino, "Fintech as Financial Innovation - The Possibilities and Problems of Implementation," European Research Studies Journal 20, No. 3 (2017): 962.

${ }^{16}$ A. Sonny Keraf, Pasar Bebas Keadilan dan Peran Pemerintah: Telaah Politik Ekonomi Adam Smith (Yogyakarta, 1996), 198.

${ }^{17}$ Adam Smith, Inquiry into the Nature and Causes of the Wealth of Nations (New York: Wilson and Son, 1809): 20.

${ }^{18}$ Ibid., 198. 
values in free-market institutions, namely a strict market order with all the rules and morality that accompanies it, and a market economy order that removes barriers to the entry and exit of goods and services.

Before the General Agreement on Trade and Tariff (GATT) in 1994 and the institutionalization of the World Trade Organization on 1 January 1995, each country had provisions regarding the entry requirements for goods and services. The provision arranged that the inflow of goods and services in each country has restrictions and cost. These restrictions were ought to be released. Every country must open a free market from their country to and from anyone parties. Allowed requirements are set by the WTO such as the (human) good's security or certain certifications set by the state authority upon arrival of goods or services originating from anywhere.

As a country that ratified the GATT and an agreement on the establishment of the WTO, Indonesia is bound and acts under the free trade. The Indonesian market is free to be entered by goods or services from anywhere, including fin-tech. Law Number 25 of 2007 concerning Investments states that investments are divided into two categories, namely:

1) Domestic investment is an investment activity to conduct business in the territory of the Republic of Indonesia carried out by local investors using domestic capital.

2) Foreign investment is an investment activity to conduct business in the territory of the Republic of Indonesia which is carried out by foreign investors, both those who use foreign capital entirely or who are collaborating with domestic investors.

This distinction is to facilitate the government in determining the status of business operators in Indonesia. In the Indonesian context, the existence of fin-tech is inseparable from applicable law. The legal provisions are the basis for the existence of a good or service in Indonesia which is further regulated in Presidential Regulation No. 39 of 2014 concerning the Negative List of Investment-then regulated in Presidential Regulation No. 44 of 2016 concerning Negative List of Investment. These provisions govern the matter of investment areas that are closed (temporary) in the territory of Indonesia. Fin-tech financial services sector is not included in the negative investment list.

In principle, Indonesia is an open area for anyone who wants to business in Indonesia, including companies that provide financial services that use applications (fin-tech). There is no diversification regarding to a businessperson country origin while performing businiess in Indonesia. Juridically, there is no provision prohibiting the implementation of fin-tech.

\section{b. Consumer Protection Regime}

Fin-tech is the latest financial services that are developing in a society whose existence is based on freedom of doing business in Indonesia. But the thing to remember is that aside from being based on legal provisions of Fin- 
tech regarding the independence of business, the holding of fin-tech implies submission to other legal provisions. As a fin-tech-based financial service, it certainly requires arrangements that not only relate to institutional requirements, service system security, data centres and other required certifications, but more importantly, is how the fin-tech financial services are provided in the community and contribute to people's lives. For that and in that position, consumer protection becomes a necessity. Without it, fin-tech financial services will only be carried out by the interests of the service providers.

The issue that emerged in fin-tech financial services was related to technology and data usage of service users. Technological progress implies a balance between the provision of fin-tech financial services and the responsibilities of fin-tech financial service providers. Utilization of fin-tech financial services will be optimal if followed by an effective legal and regulatory framework to protect service users, service providers and financial systems. ${ }^{19}$ In all three dimensions, the provisions of the fin-tech financial services consumer protection law are applied. Exactly what Halveston said to describe fin-tech.

In its infancy, the state's primary involvement in consumer protection efforts involved imposing common law liabilities on businesses for harms caused by their products. As markets evolved, the goods and services being sold to consumers became more complex, and the state instituted further forms of regulation. Legislatures passed laws establishing specific commercial standards and created administrative bodies responsible for overseeing certain market sectors. In the modern era, new regulatory measures seem an inevitable consequence of any major development in consumer markets. ${ }^{20}$

In the early days, consumer protection laws had to be attached to fintechs that had sophistication in their systems and interaction models that were different from conventional ones, so the legal relation had to refer to the applicable legal principles.

The society necessity is increasingly diverse and require speed so as not to create other problems. Fin-tech, which provides loans, payments, purchases, etc, is considered successful if it can optimize information-technology and adapt to a range of laws and obligations. ${ }^{21}$

Fin-tech which operates in Indonesia is considered successful if the service system runs well and quickly, then the attitude of its management acts to respect service users by conveying all matters relating to the services

\footnotetext{
${ }^{19}$ V. Gerard Comizio, "Virtual Currencies: Growing Regulatory Framework and Challenges In The Emerging Fintech Ecosystem," North Carolina Banking Institute 21, No. 1 (2017): 132.

${ }^{20}$ Max N. Helveston, "Regulating Digital Markets," NYU Journal of Law \& Business 13, (2016): 40.

${ }^{21}$ John L. Douglas, "New Wine into Old Bottles: Fintech Meets the Banks Regulatory World," North Carolina Banking Institute 20, No. 1 (2016), 65. https://doi.org/10.2139/ssrn.2676553. 
provided. OJK mentions fin-tech as peer to peer lending. ${ }^{22}$ Fin-tech services involve payments, loans, investments, insurance and etc. ${ }^{23}$ The fin-tech financial services are offered to the public by service providers.

Certainly, an understanding of legal provisions related to financial services and consumer protection refers to a complementary understanding, not to the context of lex specialis and lex generalis. Information disclosure is a precondition for consumer protection. Article 4 paragraph 3 of Law Number 8 Year 1999 Concerning Consumer Protection Arconfirms that the Consumer has the right to correct, clear and honest information regarding the conditions and guarantees of goods and/or services. Submitting complete and accurate information to service users is an obligation for fin-tech financial service providers. Because it describes to service users about what are their rights and obligations related to the use of fin-tech services. For deviations from the implementation of these obligations, service users can report to institutions of consumer protection, even private institutions, government institutions, and the OJK.

The role of the relevant authorities is the key to success. The experience of the UK and Australia shows the position of authority in building a healthy financial services sector from the beginning. The U.K. Financial Conduct Authority launched Project Innovate and the Innovation Hub to foster competition and growth in financial services by helping firms with new products understands and navigate the regulatory framework and apply for a business license. The Australian government has created several different outreach programs, including Australian Securities and Investments Commission's Innovation Hub, which allows businesses to request informal guidance on the licensing process, key regulatory issues, and possible waivers from licensing and authorisation requirements. ${ }^{24}$

OJK has implemented several requirements related to obtaining a business license for fin-tech financial services companies. To protect the interests of the society who use fin-tech financial services, OJK Regulation No. 77 of 2016 concerning Information-technology-Based Money Lending Services requires the fin-tech application company to submit a permit to the OJK. Until December 13, 2019, OJK noted that there were 144 companies providing peer to peer lending, including Modalku, KTA Kilat, Kredit Pinter, Maucash, Finmas and KlikACC, Akseleran, Ammana, PinjamanGo, Koinworks, Pohon Dana, Mekar.id, AdaKami, Esta Kapital, KreditPro, FINTAG, RupiahCepat, CROWDO. ${ }^{25}$ People who use fin-tech financial services use service providers registered with OJK.

\footnotetext{
${ }^{22}$ January 3, 2020. www.ojk.go.id/id/kanal/iknb.

${ }^{23}$ January 3, 2020. www.katadata.co.id.

${ }^{24}$ Nicole D. Prysby, "PEW Releases Report On International Approaches For Regulating Fintech," International Securities and Financial Reporting Update 13, No. 17 (2018): 2.

${ }^{25}$ January 3, 2020. www.ojk.go.id/id/kanal/iknb.
} 
In addition, the FSA requires, first, the fin-tech application company to obtain ISO 27001 certification for data security; second, socializing services to the public or service users; third, the use of digital signatures and applying for permission to the Ministry of Communication and Information-technology (Kominfo) regarding the application used; partner with loan collection companies registered with AFPI. ${ }^{26}$

Lastly, OJK Regulation No. 13 of 2018 concerning Digital Financial Innovation requires fin-tech application companies to build data centres, including its recovery in Indonesia. This obligation is strategic. Foreign fintech companies or those owned by foreign parties operate in Indonesia and have data centres and their improvement in Indonesia as well. This is related to millions of Indonesian citizenship service data that must be stored and restored here, if something happens with the fin-tech application or its data centre. OJK also requires Fintech service providers to protection their consumer data security. ${ }^{27}$

Normatively, technical and technological aspects related to data security, management and recovery are regulated. It is meant that the implementation of fin-tech in Indonesia has followed information-technology standards. OJK is authorized to conduct supervision on an ongoing basis and respond as soon as possible to developments or operations that are detrimental to service users. The requirements for fin-tech providers are designed to protect.

But the thing to remember is the independence and understanding of service users to get relevant information related to the use of fin-tech financial services. It began with the ability of financial service providers to explain the Fin-tech services offered to the public. Information about fin-tech financial services is essential for service users to make decisions. OJK's socialization and education to the public regarding fin-tech is not fully accessed and understood. As a result, several cases related to fin-tech is occur.

Some cases come to the surface of public life. Recorded in the mass media, there are cases of online loan customers amounting to one million IDR fined up to 30 million IDR a month. ${ }^{28}$ It is tragic if fin-tech which is expected to provide solutions and contribute to society will instead become a predator of fin-tech service users. Predatory lending methods directed at disenfranchised communities not only breached the consumer protection obligations of banks, but also severely damaged their standing. ${ }^{29}$ Fin-tech loan financial services are certainly not designed with this method and purpose.

\footnotetext{
${ }^{26}$ January 3, 2020. www.katadata.co.id

${ }^{27}$ Sari Murti Widiyastuti dan Johanes Widijantoro, "The Role of Financial Services Authority in the Consumer Protection Amid the Growth of Fintech Industry in Indonesia," Mimbar Hukum 31, No. 2 (2019): 302.

28 January 2, 2020. https://www.tribunnews.com/regional/2019/07/25/kronologi-nasabahpinjaman-online-rp-1-juta-denda-rp-30-juta-sebulan-hingga-fitnahrela-digilir.

${ }^{29}$ Arner Barberis, Buckley, Op.Cit., 1287. 
The Vloan case is one of the situations where debt collectors threaten customers through electronic media. ${ }^{30}$ Several other similar cases were reported by the mass media and followed up by the Indonesian National Police. If it is related to criminal aspects such as threatening, committing acts of violence, then the task of the Indonesian National Police is to handle it. Obviously this is contrary to OJK regulations which require fin-tech financial service providers to use billing service companies registered with AFPI. Regarding Vloan's actions, service users can use the provisions of Law Number 8 of 1999 Concerning Consumer Protection Article 4 paragraph 5, namely the right to obtain advocacy, protection, and efforts to resolve consumer protection disputes appropriately. Vloan's actions contradict these provisions.

\section{Conclusions}

Based on the discussion of the research, it has come to a conclusion that fin-tech is a financial service that provides excellence, i.e. immediate, and provides opportunities to get services without face to face. The existence of fin-tech is based on a free-market platform. There is no legal provision that says fin-tech is a closed business field. Finally, as a new line of business, fintech is not only based on the principle of freedom of business or free market but most importantly is respect for consumer rights. Furthermore, free market law and consumer protection are complementary relationships. After being permitted to operate, the provisions regarding the protection of service users become an aspect that is considered a success.

\footnotetext{
${ }^{30}$ January 2, 2020. https://www.pikiran-rakyat.com/advertorial/pr-01311000/6-deretan-kasuspinjaman-online-jangan-sampai-jadi-korban-selanjutnya.
} 


\section{References}

Rusydiana, Aam Slamet. "Bagaimana Mengembangkan Industri Fintech Syariah di Indonesia? Pendekatan Interpretive Structural Model (ISM)." Jurnal Al-Muzara'ah 6, No. 2 (2018), https://doi.org/10.29244/jam.6.2.117-128.

Bradley, Christopher G. "Fintech's Double Edges." Chicago-Kent Law Review 93, No. 1 (2018).

Cohen, Bruce. Sosiologi: Suatu Pengantar. Jakarta: Bina Aksara, (1983).

Arner, Douglas W, Jànos Barberis, Ross P. Buckley. "The Evolution of Fintech: a New Post-Crisis Paradigm?" Georgetown Journal of International Law 47, No. 4 (2016). https://doi.org/10.2139/ssrn.2676553.

Walker, George. "Financial Law: A New Beginning and a New Future." Best of ABA Section International Law 50, No. 1 (2017).

Heffernan, Shellagh. Modern Banking in Theory and Practice. New York: John Wiley and Sons, 1996.

Flocken, Katherine. "Survival of the Fin-tech: is the Sector Ready for Congress to Regulate?" Intellectual Property \& Technology Law Journal 31, No. 8 (2019).

Keraf, A. Sonny. Pasar Bebas Keadilan dan Peran Pemerintah: Telaah Politik Ekonomi Adam Smith. Yogyakarta, (1996).

Helveston, Max N. "Regulating Digital Markets." NYU Journal of Law \& Business 13. (2016).

Naisbitt, John. Megatrends Asia. Jakarta: Gramedia, 1996.

Prysby, Nicole D. "PEW Releases Report on International Approaches for Regulating Fin-tech." International Securities and Financial Reporting Update 13, No. 17 (2018).

Young, Patrick, Thomas Theys. Capital Market Revolution: The Future of Markets in an Online World. London: Prentice Hall, (1999).

Widiyastuti, Sari Murti, Johanes Widijantoro. "The Role of Financial Services Authority in the Consumer Protection amid the Growth of Fintech Industry in Indonesia." Mimbar Hukum 31, No. 2 (2019).

Smith, Adam. Inquiry into the Nature and Causes of the Wealth of Nations. York: Wilson and Son, (1809). https://doi.org/10.1093/oseo/instance.00043218.

Saksonova, Svetlana, Irina Kuzmina-Merlino. "Fintech as Financial Innovation-The Possibilities and Problems of Implementation." European Research Studies Journal 20, No. 3 (2017). https://doi.org/10.35808/ersj/757.

The Republic of Indonesia, Financial Services Authority Regulation Number 77 Year 2016 Concerning Information-technology Based Money Lending Services. 
The Republic of Indonesia, Financial Services Authority Regulation No. 13 of 2018 Concerning Digital Financial Innovations.

The Republic of Indonesia, Law Number 25 Year 2007 Concerning Investment. Republic of Indonesia State Gazette Year 2007 Number 67.

The Republic of Indonesia, Law Number 8 of 1999 Concerning Consumer Protection, State Gazette of the Republic of Indonesia of 1999 Number 42.

The Republic of Indonesia, Presidential Regulation No. 44 of 2016 Concerning List of Closed Business Fields.

The Republic of Indonesia, Presidential Regulation Number 39 Year 2014 Concerning the Negative List of Investment.

V. Gerard Comizio, (2017), "Virtual Currencies: Growing Regulatory Framework and Challenges in the Emerging Fintech Ecosystem", North Carolina Banking Institute March, 21 (1).

https://ekonomi.kompas.com/read/2017/09/25/183423826/fintech-20-dan30-apa-bedanya

https://www.andalanelektro.id

https://www.pikiran-rakyat.com/advertorial/pr-01311000/6-deretan-kasuspinjaman-online-jangan-sampai-jadi-korban-selanjutnya

https://www.tribunnews.com/regional/2019/07/25/kronologi-nasabahpinjaman-online-rp-1-juta-denda-rp-30-juta-sebulan-hinggafitnahrela-digilir

www.katadata.co.id www.ojk.go.id/id/kanal/iknb 
